\title{
Quantitative Study of the Myenteric Plexus of the Descending Colon of Young Rats Subjected to Intense Protein Deficiency
}

\author{
Estudio Cuantitativo del Plexo Mientérico del Colon Descendente \\ de Ratas Jóvenes Sometidas a Intensa Deficiencia Proteica \\ "Eduardo José de Almeida Araújo; "Débora de Mello Gonçales Sant’Ana; \\ **Sonia Lucy Molinari \&**Marcílio Hübner de Miranda Neto
}

\begin{abstract}
ARAÚJO, A. E. J.; SANT'ANA, G. D. M.; MOLINARI, S. L. \& MIRANDA NETO, M. H. Quantitative study of the myenteric plexus of the descending colon of young rats subjected to intense protein deficiency. Int. J. Morphol., 24(4):591-597, 2006.

SUMMARY: We studied the effects of a severely hypoproteic diet on the quantitative aspects of the myenteric plexus of the descending colon of young rats. Eighteen rats were divided into two groups, one of them being fed with a chow having $26 \%$ protein (control) and the other with a chow having $4 \%$ protein, balanced for minerals and vitamins, during 12 weeks. The whole-mounts of the descending colon had their myenteric neurons stained either with Giemsa or NADPH diaphorase. The rats from the experimental group had deficits of body weight $(54.23 \%)$ and area of the descending colon (48.14\%); additionally, we observed that there was no alteration in the total number of neurons of the colon, but a decrease in the number of NADPH-diaphorase positive neurons (37.80\%). The implications of these results concerning the priority that some cellular types may have when nutrients are less available are discussed.
\end{abstract}

KEY WORDS: Myenteric plexus; Protein-energy; Malnutrition (PEM); Descending colon.

\section{INTRODUCTION}

Malnutrition still is an important question of public health, encompassing sub-developed and developing countries and loci of poverty in developed countries (Mallikharjuna et al., 2002; Menno et al., 2002; Yuko et al., 2002). The replacement of a balanced diet for another having more energy than proteins is a reality in these countries, once the foods with greater protein levels are often expensive and, frequently, unavailable. In this way, we can consider that the study of the energy-protein malnutrition (PEM) is both important and contemporary.

For many years, studies have been made with the purpose of shedding some light on the effects of PEM on the structure and functioning of several metazoan species. The use of animal models in investigations of food deficiency employing known and controlled diets has the advantage of increasing the knowledge about several aspects of human malnutrition (Enwonwu \& Sreebny, 1970). Among these models, the rat has been used the most (Mello et al., 1995; Torrejais et al., 1995; Natali and Miranda-Neto, 1996; Sant'Ana et al., 1997; Meilus et al., 1998; Miranda-Neto et al., 1999; Natali et al., 2000; Sant'Ana et al., 2001; Castelucci et al., 2002; Araújo et al., 2003; Brandão et al., 2003; Natali et al., 2003; Mello et al., 2004). It is considered a good model for nutritional research due to its reduced size, reproductive behavior and adaptability to several diets (NRC, 1995).

As for the repercussions of malnutrition on the functioning of the gastrointestinal system, some findings show that generally there is poor absorption and alteration of the intestinal motility (Douglas, 2004). It is known that the regulation of this motility is made primarily by the enteric nervous system, especially the myenteric plexus, and this is the reason why the study of experimental malnutrition on the enteric neurons is considered to represent a fruitful area for the investigation of neuronal plasticity (Furness and Costa, 1987).

Considering the quantitative studies evaluating the consequences of PEM on the myenteric plexus of rats, it is observed a greater concentration of neurons per unit area, ascribed to a delayed intestinal growth (Mello et al., 1995;

\footnotetext{
* Instituto de Pesquisa, Estudos e Ambiência Científica, Universidade Paranaense. Mestrado em Ciência Animal, Umuarama, PR, Brasil.

*** Departamento de Ciências Morfofisiológicas, Universidade Estadual de Maringá (UEM), Av. Colombo, 87200-900, Maringá, PR, Brasil. Supported by Paranaense University, Brasil.
} 
Torrejais et al.; Natali \& Miranda-Neto; Recinos, 1996; Sant' Ana et al., 1997; Sant'Ana et al., 2001; Araújo et al., 2003). These studies focus, most of the times, on the duodenum (Santer \& Baker, 1988; Natali and MirandaNeto; Natali et al.; Brandão et al., 2003; Mello et al., 2004) and jejunum-ileum (Torrejais et al.; Meilus et al.; Miranda-Neto et al.). Few are those concerned with the large intestine (Mello et al., 1995; Sant'Ana et al., 1997; Sant'Ana et al., 2001; Castelucci et al., 2002), especially the descending colon (Recinos; Araújo et al.). Because of this, in this investigation we approached the effect of a hypoproteic diet on the myenteric plexus of the descending colon of young adult rats.

\section{MATERIAL AND METHOD}

We used 18 male Wistar rats (Rattus norvegicus) aging 90 days $(305.72 \pm 35.66 \mathrm{~g})$, which were placed in individual metabolic cages and kept in a room with controlled temperature $\left( \pm 25^{\circ} \mathrm{C}\right)$ and light/dark cycles $(12 / 12 \mathrm{~h})$. During the whole period, water and chow were offered ad libitum. Protocols for animal handling and killing were approved by the Committee on Ethics in Research Involving Animal Experimentation of the Paranaense University (UNIPAR), Brazil.

The animals were randomly allotted to two groups: control $(n=9)$ and experimental $(n=9)$. The control group (CG) received NUVILABÒ commercial chow. This was bromatologically analyzed and, from the results, it was calculated the components to be added to reduce the protein level to $4 \%$ while keeping the vitamin and mineral balance. This prepared chow was offered to the experimental group (EG). Thus, for each $\mathrm{kg}$ of experimental chow it was used $153.85 \mathrm{~g}$ of ground commercial chow, $53.10 \mathrm{~g}$ of a mixture of mineral salts, $172.87 \mathrm{~g}$ of sucrose as table sugar, $391.41 \mathrm{~g}$ of commercial corn starch, $140.7 \mathrm{~g}$ of vegetal oil as lipid source and $18 \mathrm{~g}$ of complex B vitamins as ground pills. The other vitamins were in excess in the commercial formulation and their supplementation was not necessary.
Water was added to allow mixture and pelletization of the chow. The pellets were dried in stove at $55^{\circ} \mathrm{C}$ and had their percentual composition assessed (Table I).

Both the CG and the EG were kept for 12 weeks and during this period, we monitored the animals' well being and weighted each rat weekly. At the end of the experiment, the rats from both groups were fasted for 12 hours and anesthetized with the following mixture, administered intramuscularly: Acepran $(1.26 \mathrm{ml} / \mathrm{Kg})+10 \%$ Ketamine $(1.26 \mathrm{ml} / \mathrm{Kg})+2 \%$ Xilazine $(0.42 \mathrm{ml} / \mathrm{Kg})$ and $1 \%$ Atropine $(0.22 \mathrm{ml} / \mathrm{Kg})$ (Pachaly et al., 2003). We carried out the laparotomy, removed the descending colon and measured its length and width with a millimeter ruler.

The descending colons of five animals of each group were washed in $0.9 \%$ saline, filled and immersed in acetic formol for 48 hours. Then they were dissected and stained with Giemsa solution (methylene blue) in Sorensen's sodium phosphate buffer pH 7.0 (Barbosa, 1978).

The descending colons of the four remaining animals of each group were washed and filled with phosphate buffer $\mathrm{pH}$ 7.4. They were fixed for 30 minutes with $4 \%$ paraformaldehyde (Merck, Darmstad, Germany) dissolved

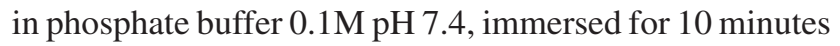
in $0.3 \%$ Triton X-100 (Sigma, St. Louis, EUA) dissolved in saline phosphate buffer (PBS) pH 7.4 and then washed 10 times (10 min each) in PBS. They were then transferred to the incubation medium for neuronal staining through NADPH diaphorase activity for two hours. This medium had, in each $100 \mathrm{ml}, 25 \mathrm{mg}$ NBT, $50 \mathrm{mg}$ b-NADPH (Sigma, Steinheim, Germany), and $0.3 \%$ Triton X-100 in Tris- $\mathrm{HCl}$ buffer (GibcoBRL, New York, EUA) 0.1M pH 6.0. After incubation, the segments were opened at the mesocolic insertion, washed three times in PBS for five minutes and immersed in 5\% paraformaldehyde solution (SchererSingler et al., 1983).

The whole-mounts were made under stereomicroscope with transillumination through removal of the mucosa and submucosa. Next, they were dehydrated in

Table I. Percentual composition of the chow offered to the control group (NUVILABÒ) and of the hypoproteic chow prepared for the experimental group.

\begin{tabular}{lcc}
\hline \multicolumn{1}{c}{ Component } & Control Chow - NUVILAB ${ }^{\circledR}(\%)$ & Experimental Chow (\%) $^{\text {(\%) }}$ \\
\hline Humidity & 8.58 & 8.9 \\
Proteins $(\% \mathrm{~N} \mathrm{x} \mathrm{6.25)}$ & 26.02 & 4.07 \\
Lipids & 6.45 & 8.8 \\
Ashes & 9.05 & 2.34 \\
Fibers & 7.24 & 60.92 \\
Carbohydrates $($ by $\neq)$ & 42.66 & $402.60 \mathrm{Kcal} / 100 \mathrm{~g}$ \\
Energy Value & $332.77 \mathrm{Kcal} / 100 \mathrm{~g}$ \\
\hline
\end{tabular}

Source: Percentual composition carried out by the Laboratory of Physic-Chemistries Analyses of the Paranaense University. 
ascending series of ethylic alcohol, cleared in xilene and mounted in slide with Permount synthetic resin (Fischer Chemical, New Jersey, EUA).

The whole mounts stained with these two techniques were used to determine the population density of the stained neurons. For that, we used an Olympus microscope and counted the number of neurons seen in 40 fields magnified 400 times, which had an area of $0.1735 \mathrm{~mm}^{2}$ each. This analysis was made in the intermediate region of the intestinal circumference $\left(60^{\circ}\right.$ to $120^{\circ}$ and $240^{\circ}$ to $300^{\circ}$, considering the mesocolic insertion as $0^{\circ}$ ).

To analyze possible significant differences on the neuronal densities between the two techniques described, we used the Mann-Whitney test, at a significance level of $5 \%$. To assess a possible significant difference between the mean weights of the two groups we employed the test $t$ at the significance level of $1 \%$. The results are presented as mean \pm standard deviation.

\section{RESULTS}

At the end of the experimental period, the animals from the control group had a mean body weight of $385.51 \pm$ $43.26 \mathrm{~g}$ and the experimental group $249.96 \pm 43.93 \mathrm{~g}$. The difference between these means attained significance $(\mathrm{p}<0.01)$.

Table II presents the length, width and area of the total colon of both groups. Table III depicts the result of the quantitative analysis on the density of myenteric neurons in the whole mounts of the descending colon of both groups. Table IV demonstrates the projection of the total number of neurons and number of NADPH-diaphorase positive neurons for the total area of the colon of the control and experimental animals.

\section{DISCUSSION}

We verified that the reduction of the protein level from $26 \%$ to $4 \%$ in the chow offered to the animals from the experimental group caused, during the experiment, body weight loss, loss of fur, cutaneousrashes, and diarrhea. These data and observations, together with the smaller growth of the colon, led us to consider that this diet was efficient in inducing malnutrition.

The protein level offered to the EG rats $(4 \%)$ was not sufficient to allow the body weight evolution of these animals, because they not only did not gain weight but also lost $18.01 \%$ of their initial weight after 12 weeks of treatment $(\mathrm{p}<0.05)$.

Table II. Mean length, width and area of the total colon of young rats from the control and experimental groups.

\begin{tabular}{lccc}
\hline \multicolumn{1}{c}{ Group } & Length $(\mathbf{m m})$ & Width $(\mathbf{m m})$ & Area $_{\left(\mathbf{m m}^{2}\right)}$ \\
\hline Control $(\mathrm{n}=9)$ & $151.0 \pm 12.9^{\mathrm{a}}$ & $15.0 \pm 0.5^{\mathrm{a}}$ & $2,265.0 \pm 208.6^{\mathrm{a}}$ \\
Experimental $(\mathrm{n}=9)$ & $120.0 \pm 10.6^{\mathrm{b}}$ & $12.8 \pm 1.4^{\mathrm{b}}$ & $1,529.0 \pm 143.9^{\mathrm{b}}$
\end{tabular}

Means followed by different letters in the same column are significantly different $(\mathrm{p}<0.05)$. The colonic area was calculated as the product of the length and width. Mean \pm standard deviation.

Table III Neuronal density of the myenteric plexus of the descending colon of young rats of the control and experimental groups, evidenced through the techniques of Giemsa and NADPH-diaphorase, in an area of $6.94 \mathrm{~mm}^{2}$ (40 microscopic fields).

\begin{tabular}{lccc}
\multicolumn{1}{c}{ Technique } & Number of animals & Control & Experimental \\
\hline Giemsa & 5 & $1,406.4 \pm 137.8^{\mathrm{a}}$ & $2,217.0 \pm 341.9^{\mathrm{b}}$ \\
NADPH-diaphorase & 4 & $779.5 \pm 123.2^{\mathrm{a}}$ & $761.0 \pm 159.2^{\mathrm{a}}$ \\
\hline
\end{tabular}

Means followed by different letters in the same line are significantly different $(\mathrm{p}<0.05)$. Mean \pm standard deviation.

Table IV. Projection of the number of neurons, stained with Giemsa and NADPH-diaphorase, for the total area of the colon of the animals from the control and experimental groups.

\begin{tabular}{lcc}
\hline \multicolumn{1}{c}{ Technique } & Control & Experimental \\
\hline Giemsa & $456,036.02 \pm 17,491.70^{\mathrm{a}}$ & $487,883.29 \pm 77,809.77^{\mathrm{a}}$ \\
NADPH-diaphorase & $237,610.32 \pm 43,897.78^{\mathrm{a}}$ & $172,432.28 \pm 56,102.34^{\mathrm{b}}$ \\
\hline
\end{tabular}

Means followed by different letters in the same line are significantly different $(\mathrm{p}<0.05)$. Mean \pm standard deviation. 
Other experimental studies using rats observed retarded body weight gain when the animals were fed with hypoproteic diet containing protein levels equal to or greater than $5 \%$ (Enwonwu et al., 1973; Natali et al.; Sant'Ana et al., 2001; Araújo et al.; Mello et al., 2004); diets with protein levels lower than $5 \%$ demonstrated absence of body weight gain and even body weight loss (Enwonwu \& Sreebny; Enwonwu et al.; Anthony \& Edozien, 1975; Castelucci et al., 2002). The reduction of the body weight probably is due to a smaller development of the fat and lean masses of these animals, which may represent an adaptive mechanism in face of the short supply of food. If this is so, the available resources are shifted to keep the metabolism of the "noble" tissues (such as the nervous system) already formed, so as to keep them in a steady-state for a longer time until the animal can find a new food source to meet the demands of the whole organism.

When we compared the area of the total colon of the animals from EG with that of $\mathrm{CG}$, we noticed that the former represented $67.51 \%$ of the latter, thus we can say that the $22 \%$ reduction of the protein in the diet of growing rats leads to a deficit of $48.14 \%$ in the expected growth of the colon. This can be linked to the reduced synthesis of essential proteins needed for cellular hyperplasia and hypertrophy, probably due to the smaller availability of exogenous aminoacids, as well as by the decreased plasma levels of insulin, an important growth-promoting factor (Guyton \& Hall, 2002). The scientific literature shows that the smaller growth of the viscera is a common feature of disnurtured children (Waterlow, 1996). A study assessing the effect of a $14 \%$-protein deficiency demonstrated a growth deficit of $57.60 \%$ in the growth of the rat colon (Recinos). Although this author supplied more protein than we did, this greater retardation of growth was probably due to the prolonged duration of the experiment (120 days); this is in agreement with prior studied that demonstrate that the cellular response to malnutrition is time-dependent (Winick \& Noble, 1966). The retarded growth of the colon is more severe when protein deficiency is associated to the lack of supplementation of complex B vitamins, as demonstrated in a 120-day experiment, in which they observed a development deficit of $92.31 \%$ (Araújo et al.).

The whole mounts of this study stained with Giemsa would have indicated that the neuronal density of the descending colon of the EG animals was greater than that of $\mathrm{CG}$, but when we consider the projection of these cells for the total colon we verify that there is no significant difference in the number of myenteric neurons between these groups. We infer that the reduced area of the colon of the EG animals is the result of a greater damaging effect of the hypoproteic (4\%) diet on the epithelial, connective and muscular tissues, which are those having greater mitotic indices and thus being affected earlier than those having a low turnover index (Deo, 1978); in this case, the myenteric neurons would be preferably preserved. Castelucci et al. (2002) subjected pregnant rats to protein privation and observed that, soon after birth, the colon of the newborn was $40 \%$ smaller than that of the controls, but the total number of neurons of the organs had not been diminished. A different result was reached when young rats were subjected to a $8 \%$-protein diet for 120 days (Recinos), and in a similar investigation but without protein supplementation (Araújo et $a l$.); in both of them there was no significant alteration in the neuronal density of the descending colon, but on the other hand a number about $48.40 \%$ smaller of myenteric neurons was obtained, when considering the projection of these cells for the whole colon. In studies evaluating the ascending colon, it was also noticed that a 8\%-protein diet offered for 120 days, either with or without complex B vitamins supplementation, caused an increase in the neuronal density and a decrease of about $36.68 \%$ in the total number of neurons (Sant'Ana et al., 1997; Sant'Ana et al., 2001). This agrees with our discussion concerning the time-dependent repercussions of malnutrition, but indicates that there is a limit for the preservation of the tissues of lower turnover.

As the digestory tract is exposed to a variety of potential injuries, Hanani et al. (2003) suggest that the myenteric plexus is endowed with a considerable ability of regeneration and plasticity, as observed in the study of Castelucci et al. (2002); they analyzed the litters of female rats disnurtured during gestation and lactation, and observed less reactive NADH-diaphorase positive neurons, but when the standard chow was offered to the weaned young rats the normal appearance of the neurons was reestablished after only 21 days. These authors also suggested that, during protein privation, the enteric neurons are protected when there is a marked deficit of body weight gain and of growth of the gastrointestinal segment, which is in agreement with our results, because we observed a severe deficit of both body weight gain $(72.01 \%)$ and colon growth $(48.14 \%)$ and no neuronal loss. On the other hand, the studies reporting neuronal loss during the experiment showed body weight gain or deficits not superior to 20\% (Recinos; Meilus et al.; Sant'Ana et al., 2001; Araújo et al.). This indicates that more studies are needed to evaluate the possible correlation between the deficit of body weight gain and the prevention of myenteric neuron loss, as well as to clarify the possible mechanisms involved in this process. Nevertheless, it should be taken into account that the experimental period, the protein level of the diet and the age of the animals are remarkable variables, much as a presumptive replacement of neurons from undifferentiated (Filagamo \& Cracco, 1995) or glial cells (Rühl et al., 2004).

As there was a smaller colonic growth of about $48.14 \%$, it would be expected that the neurons stained with NADPH-diaphorase were more concentrated in a similar 
proportion. However, we noticed that there was no alteration in the populational density of these neurons. On the other hand, when we observe the projection of the neuronal subpopulation for the whole colon we verified that $37.80 \%$ of the neurons from $E G$ rats were not reactive to the technique when compared to CG. This technique consists in the incubation of the tissues in a medium saturated with NADPH and tetrazolium so that the cells containing the NADPH-enzyme reduce the tetrazolium to formazan using the electrons from NADPH (Scherer-Singler et al., 1983). In this way, the neurons having this enzyme are highlighted from the others by the blue color of the formed salt. Neurons stained with this technique possess the enzyme nitric oxide synthase (NOS) co-localized with the NADPH-diaphorase (Young et al., 1992; Toole et al., 1998). NOS converts the aminoacid arginine to nitric oxide (NO). This is an important neurotransmitter triggering nonadrenergic, non-cholinergic (NANC) relaxation of the smooth muscle tissue (Takeuchi et al., 1998), including that of the colon (Borjesson et al., 1997; Takahashi \& Owyang, 1998). Our results allow us to infer that there was a smaller expression of the NADPH-diaphorase enzyme, possibly due to the smaller availability of aminoacids, and this may have induced the neurons having this enzyme to give priority to the synthesis of other, more essential, proteins. However, we cannot assure that in the pathologic situation of this study the co-existence of the NADPH-diaphorase with the NOS is kept in the same proportion; immunohistochemical studies for NOS are needed to test this hypothesis with this experimental model. Yet, if we consider that the lower number of NADPH-diaphorase positive neurons observed in EG is indicative of a lower production of $\mathrm{NO}$, the absence of neuronal loss in disnurtured rats can also be explained by a decreased apoptosis: many neurons release NO soon before dying, which can even lead to the death of neighboring cells because $\mathrm{NO}$ is toxic for the cells that do not produced it (Wang et al., 2003). The observation that this neuronal subpopulation tends to be preserved during the natural losses of aging sustains this (Phillips-Robert et al., 2003). In studies carried out with young and aged rats subjected to restricted offer and ingestion of food, it was demonstrated that the population of NADPH-diaphorase positive neurons was normally reduced (about 50\%) during aging when the animals were normally fed (control). However, when the animals received half the normal amount of food, the number of neurons did not decrease, showing that there was no loss in aging; even animals fed with a quarter of the normal food supply did not have neuronal loss at the age of 30 months and an increase with aging was predicted (Cowen et al., 2000).

We can suggest that the effects of malnutrition on the population of nitrergic neurons is proportional to the proteic deficit of the diet, if we compare the results of this study with a previous one, in which we assessed the effect of a less severe (8\%) hypoproteic diet and verified that there was no significant difference in the projection of NADPH-diaphorase positive neurons for the total colon (Araújo et al.). This is an indicative that there is a positive correlation between protein deficiency in the diet and a smaller NANC relaxation of the descending colon that can unbalance the mechanism of fecal propulsion in animals subjected to a severe protein restriction; excitatory neurons could predominate over the inhibitory ones, and this could be an explanation for the diarrhea in some EG rats during the experiment.

In this way, we can suggest that when a 4\%-protein is offered in association with a large energy supply to young rats, there are evidence of metabolic alterations, especially in what concerns protein synthesis, with marked damage to several tissues. Nevertheless, the use of exogenous aminoacids seems to be priority for some cellular types, in this case the neurons of the myenteric plexus, which do not show significant reduction of their total number, but did undergo metabolic modulations such as reduction in the expression of the NADPH-diaphorase enzyme. This prompt us to agree with Furness \& Costa, that put forward that the study of malnutrition is a means of understanding neuronal plasticity.

\section{ACKNOWLEDGEMENTS}

The authors are thankful to Prof. Dr. Gilberto Alves, Titular Professor of the Graduation Course in Nutrition of the Paranaense University, for his help in the preparation of the diet and for the percentual composition carried out. This study was supported by Paranaense University, Brazil.

ARAÚJO, A. E. J.; SANT'ANA, G. D. M.; MOLINARI, S. L. \& MIRANDA NETO, M. H. Estudio cuantitativo del plexo mientérico del colon descendente de ratas jóvenes sometidas a intensa deficiencia proteica. Int. J. Morphol., 24(4):591-597, 2006.

RESUMEN: Estudiamos los efectos crónicos de una dieta severamente hipoproteica sobre los aspectos cuantitativos del plexo mientérico del colon descendente de ratones jóvenes. 18 ratones fueron divididos en dos grupos, a uno de estos grupos se le dió ración con contenido proteico del $26 \%$ (control) y al otro, ración con contenido proteico del 4\%. Se mantuvo el balance vitamínico y mineral, durante 12 semanas. Elaboramos los preparados de membrana del colon descendente y marcamos las neuronas del plexo mientérico con Giemsa y NADPH-diaforasa. Los ratones del grupo experimental presentaron déficit de peso corporal $(54,23 \%)$ y del área del colon descendente $(48,14 \%)$; además, observamos que no hubo alteración en el número total de neuronas en todo el colon; sin embargo, hubo una disminución en la marcación de neuronas NADPH-diaforasa positivas (37,80\%). Los resultados son discutidos, respecto a la prioridad que ciertos tipos celulares pudiesen tener, con la menor disponibilidad de nutrientes.

PALABRAS CLAVE: Plexo mientérico, Mala nutrición proteico-energética (MPE); Colon descendente. 


\section{REFERENCES}

Anthony, L. E. \& Edozien, J. C. Experimental protein and energy deficiencies in the rat. J. Nutr., 105(6): 631-48, 1975.

Araújo, E. J. A.; Sant'Ana, D. M. G.; Molinari, S. L. \& Miranda-Neto, M. H. Effect of protein and vitamin B deficiency on the morpho-quantitative aspects of the myenteric plexus of the descending colon of adult rats. Arq. Neuropsiquiatr., 61:226-33, 2003.

Barbosa, A. J. A. Técnica histológica para gânglios nervosos intramurais em preparados espessos. Rev. Bras. Pesqui. Med. Biol., 11:95-7, 1978.

Borjesson, L.; Nordgren, S. \& Delbro, D. S. Dnp causes relaxation of rat distal colon by a purinergic and a nitrergic mechanism. Eur. J. pharmacol., 334:223-7, 1997.

Brandão, M. C. S.; De Angelis, R. C. \& De Souza, R. R. Effects of pré- and postnatal protein energy deprivation on the myenteric plexus of the small intestine: a morphometric study in weanling rats. Nutr. Res., 23:215-23, 2003.

Castelucci, P.; De Souza, R. R.; De Angelis, R. C.; Furness, J. B. \& Liberti, E. A. Effects of pre- and postnatal protein deprivation and postnatal refeeding on myenteric neurons of the rat large intestine: a quantitative morphological study. Cell Tissue Res., 310:1-7, 2002.

Cowen, T.; Johnson, R. J.; Soubeyre, V. \& Santer R. M. Restricted diet rescues rat enteric motor neurons from age related cell death. Gut, 47(5):653-60, 2000.

Deo, M. G. Cell Biology of Protein-Calorie Malnutrition. Wld. Rev. Nutr. Diet, 32:49-95, 1978.

Douglas, C. R. Fisiologia clínica do sistema digestório. Ribeirão Preto-SP, Tecmedd, 2004.

Enwonwu, C. \& Sreebny, L. M. Experimental protein-calorie malnutrition in rats. Exp. Mol. Pathol., 12:332-53, 1970.

Enwonwu, C.O.., Stambaugh, R..V.. \& Jacobson, K..L. Protein-energy deficiency in nonhuman primates: biochemical and morphological alterations. Am. J. Clin. Nutr., 26(12):1287-302, 1973.

Filagamo, G. \& Cracco, C. Models of neuronal plasticity and repair in the enteric nervous system: a review. Ital. J. Anat. Embryol., 100:185-95, 1995.
Furness, J. B. \& Costa, M. The enteric nervous system. Edimburg, Churchill Livingstone, 1987.

Guyton, A. C. \& Hall, J. E. Tratado de fisiologia médica. Rio de Janeiro, Guanabara Koogan, 2002.

Hanani, M.; Ledder, O.; Yutkin, V.; Abu-Dalu, R.; Huang, T.Y.; Härtig, W.; Vannucchi, M. G. \& Faussone-Pellegrini, M. S. Regeneration of myenteric plexus in the mouse colon after experimental denervation with benzalkonium chloride. J. Comp. Neurol., 462(3):315-27, 2003.

Mallikharjuna, R. K.; Balakrishna, N.; Hanumantha, R. D. \& Bhaskara, R. B. Nutritional status of preschool children in different agro-economic region of Andhra Pradesh. $J$. Human Ecol., 13(5):363-7, 2002.

Meilus, M.; Natali, M. R. M. \& Miranda-Neto, M. H. Study of the myenteric plexus of the ileum of rats subjected to protein undernutrition. Rev. Chil. Anat., 16:9-14, 1998.

Mello, E.V. S. L.; Stabille, S. R. \& Miranda-Neto, M .H. Effect of maternal protein deprivation on morphological and quantitative aspects of the myenteric plexus neurons of proximal colon in rats. Arq. Neuropsiquiatr., 55(1):10613, 1995.

Mello, S. T. S.; Liberti, E. A.;, Sant'Ana, D. M. G.; Molianri, S. L. \& Miranda-Neto, M. H. Estudo morfoquantitativo do plexo mioentérico do duodeno de ratos submetidos a carência de proteínas e de vitaminas do complexo B. Acta Scientiarum 26(2):251-6, 2004.

Menno, M.S.; Flora, S. M.; Lydia, D. \& Verna, D. Malnutrition in food-surplus áreas: experience from nutritional surveillance for decentralized planning in Haiti. Food and Nutrition Bulletin 23(3):253-61, 2002.

Miranda-Neto, M. H.; Molinari, S. L. \& Stabille, S. R. Morphologic and quantitative study of the myenteric neurons of the jejunum of malnourished rats (Rattus norvegicus). Arq. Neuropsiquiatr., 57(2):387-91, 1999.

Natali, M.R.M. \& Miranda-Neto, M.H. Effect of maternal proteic undernutrition on the neurons of the myenteric plexus of duodenum of rats. Arq. Neuropsiquiatr., 54: 273-9, 1996.

Natali, M. R. M.; Miranda-Neto, M. H. \& Orsi, A. M. Effects of hypoproteic diet supply on adult Wistar rats (Rattus norvegicus). Acta Scientarum, 22(2): 567-71, 2000. 
Natali, R. M.R.; Miranda-Neto, M. H. \& Orsi, A. M. Morphometry and quantification of the myenteric neurons of the duodenum of adult rats fed with hypoproteic chow. Int. J. Morphol., 21(4):273-7, 2003.

National Research Council (NRC). Nutrient requirements of laboratory animal. Washington, National Academic Press, 1995.

Pachaly, J. R.; Sant'Ana, D. M. G.; Araújo, E. J. A.; Ciffoni, E. M. G. \& Acco, A. Anesthesia of wistar rats (Rattus norvegicus) with allometrically scaled doses of ketamine, xylazine, acepromazine and atropine preliminary report. Arq. Ciênc. Vet. Zool. UNIPAR, 3(6):195-7, 2003.

Phillips-Robert, J.; Kieffer-Elizabeth, J. \& Powley-Terry, L.; Aging of the myenteric plexus: neuronal loss is specific to cholinergic neurons. Autonomic Neuroscience Basic and Clinical, 106(2):69-83, 2003.

Recinos, J. G. L. Estudo quantitative do plexo mientérico do colo descendente de ratos submetidos à desnutrição protéica. Monografia de Especialização, Universidade Estadual de Maringá, Maringá-PR, 1996.

Rühl, A.; Nasser, Y.; Sharkey, K.A. Enteric glia. Neurogastroenterol. Motil., 16:44-9, 2004.

Sant'Ana, D. M. G.; Miranda-Neto, M. H.; Souza, R. R. \& Molinari, S. L. Morphological and quantitative study of the myenteric plexus of the ascending colon of rats subjected to proteic desnutrition. Arq. Neuropsiquiatr., 55(3):687-95, 1997.

Sant'Ana, D. M. G.; Molinari, S. L. \& Miranda-Neto, M. H. Effects of protein and vitamin B deficiency on blood parameters and myenteric neurons of the colon of rats. Arq. Neuropsiquiatr., 59(3): 493-8, 2001.

Santer, R. M. \& Baker, D. M. Enteric neuron numbers and size in Auerbach's plexus in the small and large intestine of adult and aged rats. J. Auton. Nerv. Syst., 28:59-67, 1988.

Scherer-Singler, U.; Vicent, S. R.; Kimura, H. \& Mcgeer, E. G. Demonstration of a unique population of neurons with NADPH-diaphorase histochemistry. J. Neurosci. Methods, 9:229-34, 1983.

Takahashi, T. \& Owyang, C.. Regional differences in the nitrergic innervation between the proximal and the distal colon in rats. Gastroenterology, 115:1504-9, 1998.
Takeuchi, T.; Niioka, S.; Yamaji, M.; Okishio, Y.; Ishii, T.; Nishio, H.; Takatsuji, K. \& Hata, F. Decrease in participation of nitric oxide in nonadrenergic noncholinergic relaxation of rat intestine with age. Jpn. J. Pharmacol., 78(3):293-302, 1998.

Toole, L.; Belai, A. \& Burnstock, G. A neurochemical characterisation of the golden hamster myenteric plexus. Cell Tissue Res., 291(3):385-94, 1998.

Torrejais, M. M.; Natali, M. R. M.; Conegero, C. I. \& Miranda-Neto, M. H. Effect of protein malnutrition after breast-feeding on the morphology of the intestinal wall and myenteric neurons of the ileum rats. Rev. Unimar, 17(2): 315-27, 1995

Wang, J.Y.; Shum, A.Y.; Ho, Y. J. \& Wang, J. Y. Oxidative neurotoxicity in rat cerebral cortex neurons: synergistic effects of $\mathrm{H}_{2} \mathrm{O}_{2}$ and $\mathrm{NO}$ on apoptosis involving activation of p38 mitogen-activated protein kinase and caspase-3. J. Neurosci. Res., 72(4):508-19, 2003.

Waterlow, J. C. Malnutrición proteico-energetica. Washington, OPS, 1996.

Winick, M. \& Noble, A. Cellular response in rats during malnutrition at various ages. J. Nutrition., 89:300-6, 1966.

Young, H. M.; Furness, J. B.; Shuttleworth, C. W. R.; Bredt, D. S. \& Snyder, S. H. Co-localization of nitric oxide synthase immunoreactivity and NADPH diaphorase staining in neurons of the guinea-pig intestine. Histochemistry, 97:375-8, 1992.

Yuko, T.; Boonyong, K.; Nonglak, P. \& Kanittha, C. Nutritional status of the preschool children of the Klong Toey slum, Bangkok. Southeast Asian Journal of Tropical Medicine and Public Health 33(3):628-37, 2002.

Correspondence to:

Profa. Dra. Débora de Mello Gonçales Sant'Ana

Rua Herminia Ageu Conticelli, 2563

Parque Cidade Jardim

CEP: $87506-140$

Umuarama - $P R$

BRASIL

Received: 28-06-2006

Accepted: 18-08-2006 